\title{
Prediction of Acute Organophosphate Poisoning Using Glasgow Coma Sale, Serum Cholinesterase and S100B
}

\author{
Merfat Oreby and Enas Ibraheem El-Madah ${ }^{1}$
}

${ }^{1}$ Department of Forensic Medicine and Clinical Toxicology, Faculty of Medicine, Tanta University, Tanta, Egypt.

\begin{abstract}
Background: organophosphate (OP) poisoning is a major health problem worldwide, especially in developing countries, with millions of cases and hundreds thousands of deaths occurring each year.

The aim of this study: was to evaluate the role of Glasgow Coma Sale (GCS), serum cholinesterase (SChE) and S100B protein levels in evaluation and prediction of outcome of patients with acute organophosphate poisoning.

Material and methods: the present study was conducted on admitted patients with acute organophosphate poisoning in Tanta Toxicological Unit, Tanta University Hospital during the period from the start of July 2014 to the end of June 2015. For all patients; personal and toxicological history, complete clinical examination and measurement of SChE and S100B at admission and after 24hrs were performed for every patient. Outcome assessment; the patients were divided into two groups; group (1) included patients who survived and group (2) included patients who died.

Results: the present study was carried out on 24 patients with acute severe organophosphate toxicity, their age ranged from 16-48 years. Sixteen patients (66.67\%) were survived and eight (33.3\%) were died. About two third of the patients were female (66.67\%), half of them were students (50\%) and took malathion (50\%). All patients took organophosphates orally and in a suicidal attempt. The GCS was higher in survived patients (6-11) than died ones (3-5). Additionally, serum S100B level at both admission and after 24hrs, revealed significant increase in its level in died patients than survived. While, SChE showed non-significant decrease in both survived and died patients. SChE and S100B at both admission and after 24hrs cannot predict mortality. However, GCS can predict mortality with $100 \%$ sensitivity and $75 \%$ specificity at a cut off level of 9 .

Conclusion: both GCS and S100B had significant correlation with the patients' outcome. Inspite of that, only GCS can predict mortality in $100 \%$ of the patients who has a GCS equal to or lower than 9. Also, $75 \%$ of survivors had GCS above this cut off value.
\end{abstract}

\footnotetext{
Introduction

$\mathrm{O}$ rganophosphates are the most widely used pesticides for killing agricultural pests all over the world as a result of its availability, low coast, and rapid degradation. Despite all efforts to improve management of them, accidental and suicidal ingestion is still a major public health problem. They are life-threatening condition associated with high morbidity and mortality especially in developing countries (Coskun et al., 2015).

Organophosphates compounds deposit a phosphoryl group at acetylcholinesterase enzyme resulting in its inhibition at the muscarinic and nicotinic synapses. The net effect is accumulation of acetylcholine and uncontrolled activation of cholinergic synapses (Costa, 2006; Jokanović, 2009). Furthermore, glia and neurons apoptotic death may be
}

another mechanism of OP poisoning (Bozkurt et al., 2010).

Glia are the most common cells in the brain, providing critical nutritional, structural, and homeostatic support that is essential to the architectural modeling of the brain and to the establishment and maintenance of synaptic function (Garcia et al., 2001). Astroglial cells are known to be as sensitive as neurons to hypoxic stress. Therefore, a marker for astroglial cell damage may indirectly reflect neuronal damage (Bottiger et al., 2001).

The protein S100 is a calcium-binding protein that has various effects on glia and neurons. There are 19 S-100 proteins, 4 subtypes present in human tissue: S-100A1 (striated muscles, heart, and kidneys), S100A1B (astroglial cells), S-100B (astroglial and 
Schwann cells), and S-100BB (astroglial cells) (Bottiger et al., 2001). S100B is expressed mainly in astrocytes of the central nervous system (CNS) (Yardan et al., 2009; Bozkurt et al., 2010).

S100B is an established peripheral biomarker of blood-brain-barrier permeability associated with various CNS injuries or degeneration such as traumatic cortical injury and cerebrovascular insults as well as in some psychiatric disorders (Rothermundt et al., 2003), cardiac arrest or surgery (Qiao et al., 2001; Caughlan et al., 2004). Normal levels reliably exclude major CNS pathology (Guizzetti et al., 2005; Bozkurt et al., 2010). S100B may be a potential new marker in clinical toxicology; it was associated with level of consciousness in carbon monoxide poisoning, benzodiazepine, and aluminum phosphide toxicity (Ambrozic et al., 2008; Yardan et al., 2009; Cakir et al., 2010; Shahin et al., 2016).

Sun et al., 2015 reported that reliable predictors of prognosis can instruct treatment and clinical research on antidotes and therapies. So, the aim of this study was to evaluate the role of Glasgow Coma Sale, serum cholinesterase and S100B protein levels in evaluation and prediction of outcome in patients with acute organophosphate poisoning.

\section{Patients and methods}

Ethical consideration:

This is a cohort study that was conducted on admitted patients with acute organophosphate poisoning in Tanta Toxicological Unit, Tanta University Hospital during the period from the start of July 2014 to the end of June 2015. The study was approved by Research Ethics Committee of Tanta Faculty of Medicine and the head of Tanta Toxicological Unit. A written informed consent was obtained from each participant or his guardians. Confidentiality of the patients' data was maintained by giving a code number for each patient.

Patients aged 18 years old or more with acute severe OP poisoning were included in the study. Patients with co-ingestion of other drugs, carbamate poisoning, co-morbid diseases, malignancies and inflammatory disease were excluded from the study. At first, diagnosis of organophosphate poisoning in our unit is usually based on history of exposure and the presence of muscarinic and or nicotinic manifestations. Then, confirmation occurs after estimation of SChE activity.

According to Kumar et al., (2010), severe OP poisoning was based on the presence of the following manifestations; unconsciousness, marked miosis with loss of pupillary reflex to light, muscle fasciculations, flaccid paralysis, pulmonary rales, and respiratory distress.

Patients received standard medical care in the form of emergency and supportive measures, decontamination and antidotes (atropine and toxogonin) as indicated according to the protocol of Tanta Toxicological Unit.

All the patients were subjected to the followings:

Complete personal history: name, age, sex, occupation, and residence.
- Toxicological history: type of organophosphate compound, delay time, mode and rout of exposure, number of atropine and toxogonine ampoules, and hospitalization period.

- Complete physical examination (it included pupil size, vital signs, level of consciousness, and systems examination (central nervous, respiratory, cardiovascular, gastrointestinal and urinary systems) to select the severe cases of organophosphate toxicity.

- Outcome assessment: the patients were divided into two groups; group (1) included patients who survived and group (2) included patients who died.

- Laboratory investigations: six ml of blood were withdrawn from each patient at admission before receiving any treatment and another $6 \mathrm{ml}$ were withdrawn 24 hours after admission. Three ml was used for estimation of cholinesterase level and the other $3 \mathrm{ml}$ for quantitation of $\mathrm{S} 100 \beta$.

a- Quantitation of S100 $\beta$ was performed by a double-antibody sandwich enzymelinked immunosorbent assay (ELISA) using Human (S100ß) ELISA Kit (Shanghai Sunred Biological Technology Co., Ltd, shanghai, China) according to the manufacturers' instructions. The reference cut-off level for diagnostic purpose is $>0.10 \mu \mathrm{g} / \mathrm{L}$ (Undén and Romner, 2009).

b- Serum cholinesterase level was done using CHOLINESTERASE BTC/DTNB commercial kit (It is a cholinesterase quantitative colorimetric kinetic assay; butyrilthiocholine (BTC) and dithiobisnitrobenzoic acid (DTNB) method done on serum and plasma, supplied by Science and Technology Center, www.Biostc.com, Egypt) according to the manufacturers' instructions. Normal value is 4900 11900 U/L (Burtis and Ashwood, 1999).

\section{Statistical analysis:}

The data were statistically analyzed using SPSS software statistical computer package version 18. For quantitative data, the median and range were calculated. For comparison between groups in quantitative data, Mann-Whitney U was used. For qualitative data, comparison between two or more groups was done using Chi-square. The strength of the linear association between two variables was quantified by Spearman correlation coefficient test. Receiver operating characteristics (ROC) curve was performed to determine cut off value, sensitivity, and specificity for prediction of outcome. Significance was adopted at $\mathrm{p}<0.05$.

\section{Results}

The present study was carried out on 24 patients with severe organophosphate toxicity, their age ranged from 16-48 years. 16 patients were survived and 8 were died. About two third of the patients were female 
(66.67\%), half of them were students (50\%) and took malathion (50\%). All patients took organophosphates orally and in a suicidal attempt (data not shown in the table). The time from organophosphates intake to the hospital arrival was longer in died patients (3-4 hrs.) than survived patients (0.5-2 hrs.). The GCS of all patients ranged from 3-11 with the score was higher in survived patients (6-11) than died (3-5). All patients received atropine in a dosage ranged from 7-42 ampoules and 5-52 ampoules of toxogonine. The hospital stay was ranged from 1.5-18 days in addition, the hospital stay was prolonged in died patients (12-18 days) than survived (1.5-18 days). There was significant correlation between occupation, delay time and GCS with patients' outcome (table 1).

Table 2 revealed that the serum level of S100B either at admission or after 24hrs had significant association with the patients outcome as the level of it was high in died patients compared to survived patients. On the other hand, serum cholinesterase level at admission or after 24hrs had no association with the patients' outcomes.
Both serums S100B at admission and after 24hrs showed significant negative correlation with GCS and cholinesterase level at admission and after 24hrs. However, they revealed significant positive correlation with occupation and numbers of atropine ampoules as shown in table 3 .

Table 4 illustrated significant negative correlation between numbers of atropine ampoules and occupation with cholineesterase level at admission and after $24 \mathrm{hrs}$.

In the present study, at a cut off 9 for GCS; the sensitivity was $100 \%$ and specificity was $75 \%$ with the area under the ROC curve was 1 . This means that we can predict mortality or poor prognosis in $100 \%$ of the patients who has a GCS equal to or lower than 9 . Also, $75 \%$ of survivors had GCS levels above the cut off value. On contrary, serum cholinesterase and S100B levels at admission or after $24 \mathrm{hr}$ showed nonsignificant prediction of mortality (table 5 and figure 1\&2).

Table (1): Association between patients' outcome and toxicological data at admission

\begin{tabular}{|c|c|c|c|c|c|c|}
\hline 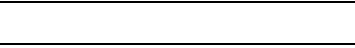 & & Patients' & me & & & \\
\hline Variables & & $\begin{array}{l}\text { Survived } \\
(\mathrm{n}=16)\end{array}$ & $\begin{array}{l}\text { Died } \\
(n=8)\end{array}$ & $\begin{array}{l}\text { Total } \\
(n=24)\end{array}$ & $\begin{array}{l}\text { Test } \\
\text { statistic }\end{array}$ & $\begin{array}{l}\text { P- } \\
\text { value }\end{array}$ \\
\hline \multirow[b]{2}{*}{ Age (years) } & Median & 19 & 32 & 8 & \multirow[b]{2}{*}{$Z_{\mathrm{MW}}=1.055$} & \multirow[b]{2}{*}{0.29} \\
\hline & $\begin{array}{l}\text { Minimum- } \\
\text { maximum }\end{array}$ & $18-43$ & $16-48$ & $16-48$ & & \\
\hline \multirow{2}{*}{ Sex } & Male & $4(25 \%)$ & $4(50 \%)$ & $8(33.33 \%)$ & \multirow{2}{*}{$\mathrm{X}^{2} \mathrm{Chs}=1.47$} & \multirow{2}{*}{0.36} \\
\hline & Female & $12(75 \%)$ & $4(50 \%)$ & $16(66.67 \%)$ & & \\
\hline \multirow{4}{*}{ Occupation } & Student & $8(50 \%)$ & $4(50 \%)$ & $12(50 \%)$ & \multirow{4}{*}{$\mathrm{X}^{2} \mathrm{ChS}=12$} & \multirow{4}{*}{$0.007 *$} \\
\hline & Employed & $4(25 \%)$ & 0 & $4(16.67 \%)$ & & \\
\hline & Housewife & $4(25 \%)$ & 0 & $4(16.67 \%)$ & & \\
\hline & Unemployed & 0 & $4(50 \%)$ & $4(16.67 \%)$ & & \\
\hline \multirow{3}{*}{ Type } & Malathion & $8(50 \%)$ & $4(50 \%)$ & $12(50 \%)$ & \multirow{3}{*}{$\mathrm{X}^{2} \mathrm{ChS}=3$} & \multirow{3}{*}{0.22} \\
\hline & Chlorpyrifos & $4(25 \%)$ & 0 & $4(16.67 \%)$ & & \\
\hline & Others & $4(25 \%)$ & $4(50 \%)$ & $8(33.33 \%)$ & & \\
\hline \multirow[b]{2}{*}{ Delay time (hours) } & Median & 1 & 3.5 & 1.5 & \multirow[b]{2}{*}{$\mathrm{Z}_{\mathrm{MW}}=4.03$} & \multirow[b]{2}{*}{$0.000 *$} \\
\hline & $\begin{array}{l}\text { Minimum- } \\
\text { maximum }\end{array}$ & $0.5-2$ & $3-4$ & $0.5-4$ & & \\
\hline \multirow[b]{2}{*}{ GCS } & Median & 6.5 & 4 & 6 & \multirow[b]{2}{*}{$Z_{M W}=4.029$} & \multirow[b]{2}{*}{$0.000 *$} \\
\hline & $\begin{array}{l}\text { Minimum- } \\
\text { maximum }\end{array}$ & $6-11$ & $3-5$ & $3-11$ & & \\
\hline \multirow[b]{2}{*}{$\begin{array}{l}\text { Number of atropine } \\
\text { ampoules }\end{array}$} & Median & 24.5 & 35.5 & 33 & \multirow[b]{2}{*}{$\mathrm{Z}_{\mathrm{MW}}=1.51$} & \multirow[b]{2}{*}{0.13} \\
\hline & $\begin{array}{l}\text { Minimum- } \\
\text { maximum }\end{array}$ & $7-42$ & $33-38$ & $7-42$ & & \\
\hline \multirow[b]{2}{*}{$\begin{array}{l}\text { Number of toxogonine } \\
\text { ampoules }\end{array}$} & Median & 19 & 26.5 & 19 & \multirow[b]{2}{*}{$\mathrm{Z}_{\mathrm{MW}}=0.504$} & \multirow[b]{2}{*}{0.614} \\
\hline & $\begin{array}{l}\text { Minimum- } \\
\text { maximum }\end{array}$ & $5-52$ & $8-45$ & $5-52$ & & \\
\hline \multirow[b]{2}{*}{ Hospital stay (days) } & Median & 9.5 & 15 & 14 & \multirow[b]{2}{*}{$\mathrm{Z}_{\mathrm{MW}}=1.51$} & \multirow[b]{2}{*}{0.13} \\
\hline & $\begin{array}{l}\text { Minimum- } \\
\text { maximum }\end{array}$ & $1.5-18$ & $12-18$ & $1.5-18$ & & \\
\hline
\end{tabular}

$Z_{M W}=$ Mann-Whitney test, $X^{2}$ ChS $=$ Chi-square test for association, * Significant at $P<0.05 \quad n=$ number. 
Table (2): Mann-Whitney test of association between patients' outcome and cholinesterase \& S100B at admission and after $24 \mathrm{~h}$

\begin{tabular}{|c|c|c|c|c|c|c|}
\hline \multirow[b]{2}{*}{ Variables } & & \multicolumn{2}{|c|}{ Outcome } & \multirow[b]{2}{*}{$\begin{array}{c}\text { Total } \\
(n=24)\end{array}$} & \multirow[b]{2}{*}{$\begin{array}{c}\text { Mann-Whitney } \\
\text { test }\end{array}$} & \multirow[b]{2}{*}{$\begin{array}{c}\text { P- } \\
\text { value }\end{array}$} \\
\hline & & $\begin{array}{l}\text { Survived } \\
(n=16)\end{array}$ & $\begin{array}{l}\text { Died } \\
(n=8)\end{array}$ & & & \\
\hline \multirow{2}{*}{$\begin{array}{l}\text { Cholinesterase } \\
\text { (U/L) } \\
\text { (at admission) }\end{array}$} & Median & 661 & 612 & 661 & \multirow[b]{2}{*}{4.8} & \multirow[b]{2}{*}{0.32} \\
\hline & $\begin{array}{l}\text { Minimum- } \\
\text { maximum }\end{array}$ & $622-1180$ & $476-748$ & $476-1180$ & & \\
\hline \multirow{2}{*}{$\begin{array}{l}\text { Cholinesterase } \\
\text { (U/L) } \\
\text { (after 24hrs) }\end{array}$} & Median & 566.5 & 592 & 566.5 & \multirow[b]{2}{*}{6.4} & \multirow[b]{2}{*}{1} \\
\hline & $\begin{array}{l}\text { Minimum- } \\
\text { maximum }\end{array}$ & $512-707$ & $387-797$ & $387-797$ & & \\
\hline \multirow[b]{2}{*}{$\begin{array}{l}\mathrm{S} 100 \mathrm{~B}(\mu \mathrm{g} / \mathrm{L}) \\
\text { (at admission) }\end{array}$} & Median & 1007.5 & 1206.5 & 1091 & \multirow[b]{2}{*}{1.99} & \multirow[b]{2}{*}{$0.04 *$} \\
\hline & $\begin{array}{l}\text { Minimum- } \\
\text { maximum }\end{array}$ & $207.5-1452.8$ & $\begin{array}{l}871- \\
1542 \\
\end{array}$ & $\begin{array}{l}207.5- \\
1542 \\
\end{array}$ & & \\
\hline \multirow[b]{2}{*}{$\begin{array}{r}\text { S100B ( } \mu \mathrm{g} / \mathrm{L}) \\
\text { (after 24hrs) }\end{array}$} & Median & 926.9 & 1154 & 946 & \multirow[b]{2}{*}{1.98} & \multirow[b]{2}{*}{$0.04 *$} \\
\hline & $\begin{array}{l}\text { Minimum- } \\
\text { maximum }\end{array}$ & $\begin{array}{l}198.6- \\
1363.9-\end{array}$ & $\begin{array}{l}710- \\
1598\end{array}$ & $\begin{array}{l}198.6- \\
1598\end{array}$ & & \\
\hline
\end{tabular}

* Significant at $P<0.05 \quad n=$ number

Table (3): Spearman's correlation between serum S100B at admission and after 24 hours with some clinical and laboratory data

\begin{tabular}{|c|c|c|c|}
\hline \multicolumn{2}{|l|}{ Variables } & \multirow{2}{*}{$\begin{array}{c}\begin{array}{c}\text { Serum S100B } \\
(\mu \mathrm{g} / \mathrm{L}) \text { at admission }\end{array} \\
0.174 \\
\end{array}$} & \multirow{2}{*}{$\begin{array}{c}\begin{array}{c}\text { Serum S100B } \\
(\mu \mathrm{g} / \mathrm{L}) \text { after } 24 \text { hours }\end{array} \\
0.087\end{array}$} \\
\hline & $\mathrm{r}_{\mathrm{S}}$ & & \\
\hline Delay time (hours) & $\mathrm{P}$ & 0.416 & 0.686 \\
\hline \multirow[b]{2}{*}{ GCS } & $\mathrm{r}_{\mathrm{S}}$ & -0.580 & -0.580 \\
\hline & $\mathrm{P}$ & $0.003 *$ & $0.003 *$ \\
\hline \multirow{2}{*}{ No of atropine ampoules } & $\mathrm{r}_{\mathrm{s}}$ & 0.522 & 0.754 \\
\hline & $\mathrm{P}$ & $0.009 *$ & $0.000 *$ \\
\hline \multirow{2}{*}{ No of Toxogonine ampoules } & $\mathrm{r}_{\mathrm{S}}$ & -0.116 & -0.029 \\
\hline & $\mathrm{P}$ & 0.590 & 0.893 \\
\hline \multirow[t]{2}{*}{ Cholinesterase (at admission) } & $\mathrm{r}_{\mathrm{S}}$ & -0.943 & -0.943 \\
\hline & $\mathrm{P}$ & $0.000 *$ & $0.000^{*}$ \\
\hline \multirow{2}{*}{ Cholinesterase (after 24hrs) } & $\mathrm{r}_{\mathrm{s}}$ & -0.600 & -0.714 \\
\hline & $\mathrm{P}$ & $0.002 *$ & $0.000^{*}$ \\
\hline \multirow[t]{2}{*}{ Serum S100B (after 24hrs) } & $\mathrm{r}_{\mathrm{s}}$ & 0.943 & - \\
\hline & $\mathrm{P}$ & $0.000 *$ & - \\
\hline \multirow[t]{2}{*}{ Occupation } & $\mathrm{r}_{\mathrm{s}}$ & 0.698 & 0.516 \\
\hline & $\mathrm{P}$ & $0.000 *$ & $0.010^{*}$ \\
\hline \multirow{2}{*}{ Hospital stay (days) } & $\mathrm{r}_{\mathrm{S}}$ & -0.058 & 0.058 \\
\hline & $\mathrm{P}$ & 0.788 & 0.788 \\
\hline
\end{tabular}

GCS: Galscow coma scale, $\mathrm{r}_{\mathrm{s}}$ : correlation coefficient of Spearman's correlation, * significant at $\mathrm{P}<0.05$.

Table (4): Spearman's correlation between serum cholinesterase at admission and after 24 hours with some clinical and laboratory data

\begin{tabular}{|c|c|c|c|}
\hline \multicolumn{2}{|c|}{ Variables } & $\begin{array}{c}\text { Serum Cholinesterase (at } \\
\text { admission) }\end{array}$ & $\begin{array}{c}\text { Serum Cholinesterase } \\
\text { (after 24hrs) }\end{array}$ \\
\hline \multirow{2}{*}{ Delay time (hours) } & $\mathrm{r}_{\mathrm{s}}$ & -0.029 & 0.116 \\
\cline { 2 - 4 } & $\mathrm{P}$ & 0.893 & 0.590 \\
\hline \multirow{2}{*}{ GCS } & $\mathrm{r}_{\mathrm{s}}$ & 0.290 & -0.087 \\
\cline { 2 - 4 } & $\mathrm{P}$ & 0.169 & 0.686 \\
\hline \multirow{2}{*}{ No of atropine ampoules } & $\mathrm{r}_{\mathrm{s}}$ & -0.522 & -0.696 \\
\cline { 2 - 4 } & $\mathrm{P}$ & $0.005^{*}$ & $0.000^{*}$ \\
\hline \multirow{2}{*}{ No of toxogonine ampoules } & $\mathrm{r}_{\mathrm{s}}$ & 0.058 & 000 \\
\cline { 2 - 4 } & $\mathrm{P}$ & 0.788 & -0.577 \\
\hline \multirow{2}{*}{ Occupation } & $\mathrm{r}_{\mathrm{s}}$ & -0.820 & $0.003^{*}$ \\
\cline { 2 - 4 } & $\mathrm{P}$ & $0.000^{*}$ & 000 \\
\hline \multirow{2}{*}{ Hospital stay (days) } & $\mathrm{r}_{\mathrm{s}}$ & 0.058 & 1 \\
\cline { 2 - 4 } & $\mathrm{P}$ & 0.788 & \multicolumn{1}{c}{. } \\
\hline
\end{tabular}

GCS: Galscow coma scale, $\mathrm{r}_{\mathrm{s}}$ : correlation coefficient of Spearman's correlation, * significant at $\mathrm{P}<0.05$. 
Table (5): Analysis of receiver operating characteristic (ROC) curve

\begin{tabular}{|c|l|l|l|l|l|}
\hline Test Variables & $\begin{array}{c}\text { Area under the } \\
\text { curve }\end{array}$ & $\begin{array}{l}\text { Standard. } \\
\text { Error }\end{array}$ & $\begin{array}{c}\text { P- } \\
\text { value }\end{array}$ & \multicolumn{2}{|c|}{$\begin{array}{c}\text { Asymptotic 95\% Confidence } \\
\text { Interval }\end{array}$} \\
\hline $\begin{array}{c}\text { GCS } \\
\text { Serum Cholinesterase(U/L) } \\
\text { (at admission) }\end{array}$ & 1.000 & 0.000 & $0.000 *$ & 1.000 & 1.000 \\
\hline $\begin{array}{c}\text { Serum Cholinesterase(U/L) (after } \\
\text { 24hrs) }\end{array}$ & 0.500 & 0.144 & 0.327 & 0.342 & 0.908 \\
\hline $\begin{array}{c}\text { Serum S100B } \\
(\mu g / L) \text { at admission }\end{array}$ & 0.750 & 0.177 & 1 & 0.154 & 0.846 \\
\hline $\begin{array}{c}\text { Serum S100B } \\
(\mu g / L) \text { after 24 hours }\end{array}$ & 0.750 & 0.110 & 0.05 & 0.533 & 0.967 \\
\hline
\end{tabular}

GCS: Galscow coma scale, * significant at $\mathrm{P}<0.05$

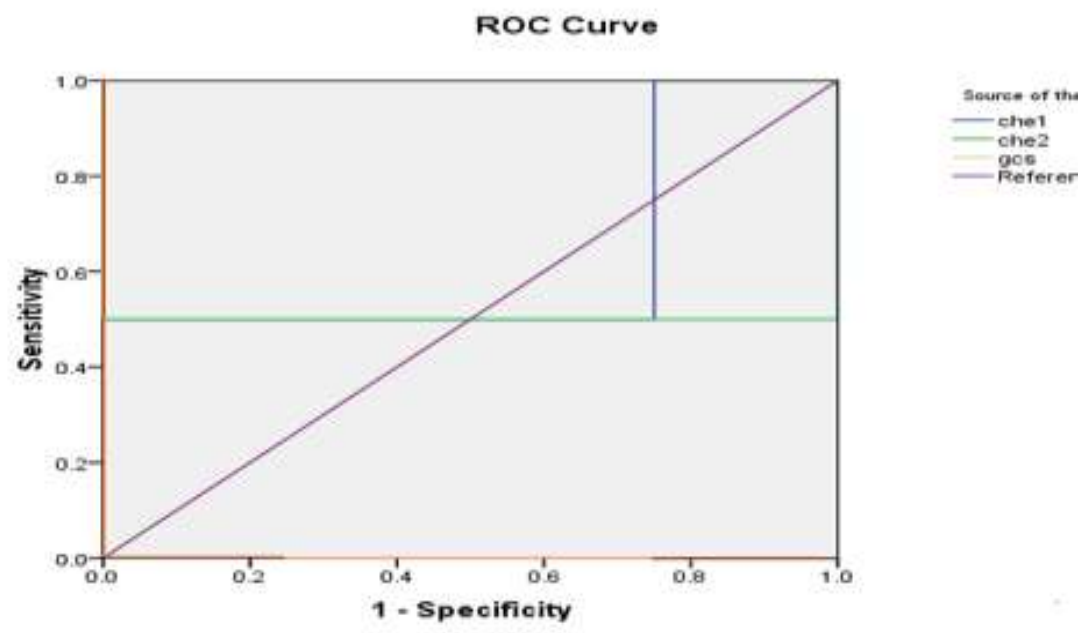

Figure (1): Receiver operating characteristic (ROC) curve analysis (Glasgow coma scale (GCS) and Serum Cholinesterase at admission (che1) and after 24hrs (che2) as predictor of outcome)

ROC Curve

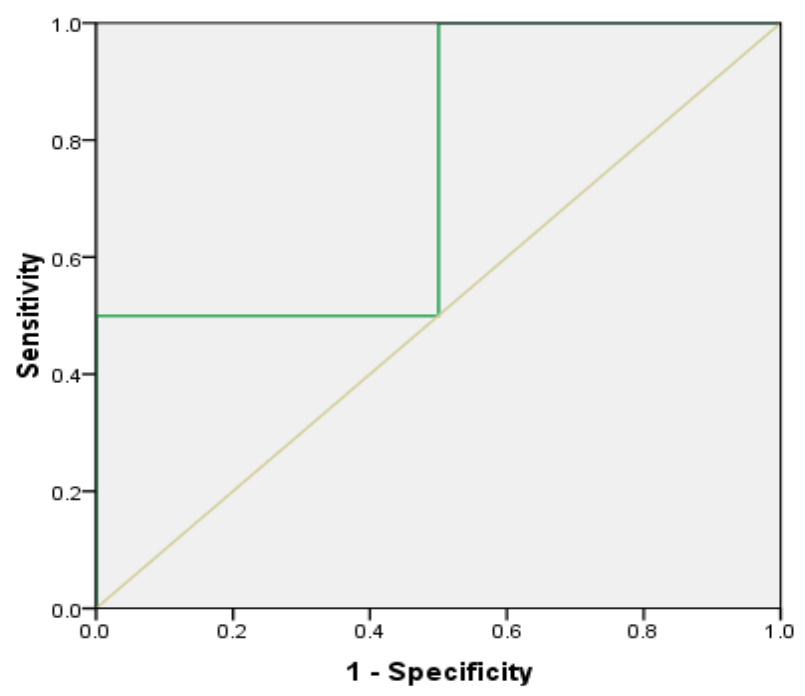

Source of the Curve

$-s 1$ Reference Line

Figure (2): Receiver operating characteristic (ROC) curve analysis (Serum S100B at admission (s1) and after $24 \mathrm{hrs}$ (s2) as predictors of outcome) 


\section{Discussion}

All over the world, especially in developing countries, organophosphorus compounds toxicity is a major health problem with millions of patients' morbidity and mortality every year (Brahmi et al., 2006).

The present study was carried out on 24 patients with severe organophosphate toxicity, their age ranged from 16-48 years. About two thirds of the patients were females (66.67\%), and half of them were students (50\%). All patients were from rural areas and took organophosphates orally and in a suicidal attempt. This is in partial accordance with Chaudhary et al., (2013) who revealed in their study on OP in north India that the majority of the patients were males (70\%), farmers between 20-30 years from rural areas (71.43\%), and ingesting OP in suicidal intent. Moreover, Hiremath et al., (2016) found that most OP patients were young males from rural areas with suicidal intent and ingestion was the main rout of exposure.

In the present study, the most common OP compound detected was malathion (50\%) followed by chlorpyrifos. In a study of Sun et al., (2015), the most common compounds were dichlorvos then phosphamidon, and the least one was methidathion and fenitrthion.

Mortality rate in the present study was $33.3 \%$. Lee et al., (2013) reported that mortality was 22.9\%. However, a $12 \%$ death rate was recorded by Sun et al., (2015), he reflected this low mortality to proper atropine administration and close monitoring of intoxicated patients in intensive care unit. The high mortality rate in the current study could be attributed to the inclusion criteria which select only severely intoxicated patients.

In this study, the time from organophosphates intake to the hospital arrival was longer in died patients (3-4hrs) than survived patients (0.5-2hrs). In agreement with this, Abedin et al., (2012) reported an increase in mortality rate in case of organophosphate with delayed transport to the hospital after exposure. As the time interval between exposures to appearance of symptoms depends on the route and magnitude of exposure; symptoms usually appear within minutes after severe ingestion (Karanth et al., 2006).

Glasgow coma score is an efficient and rapid tool for the determination of the severity and prognosis in patients with OP poisoning (Sam et al., 2009; Akdur et al., 2010). The GCS was higher in survived patient (6-11) than died ones (3-5). Likewise, GCS showed a significant negative correlation with serum S100B at both admission and after 24hrs. Yardan et al., (2013) revealed also similar results. This could be attributed to the fact that the presence of S-100B in patients' serum indicates damage to the brain and blood-brain barrier (Bottiger et al., 2001). Additionally, GCS is an accepted standard for evaluation of mental state in the acutely ill patient and assists in predictions of patients' neurological outcomes and mortality (Tien et al., 2006).

In the current work, at a GCS of 9; the sensitivity was $100 \%$ and specificity was $75 \%$ with the area under the curve was 1 . This means that we can predict mortality or poor prognosis in $100 \%$ of the patients who has a GCS equal to or lower than 9 . Davies et al., (2008) showed that patients with GCS $\leq$ 13 had $79 \%$ sensitivity and $79 \%$ specificity so, they require intense management. Furthermore, Muley et al., (2014) revealed that GCS can identify organophosphorus intoxicated patients who require special care. Similarly, Hosseini and Ramazani, (2015) recorded that cut off score 8.5 of GCS had $82.8 \%$ and $82.6 \%$ sensitivity and specificity respectively with the area under the curve equal 0.861 .

Regarding serum cholinesterase level, this study revealed non- significant decrease in the level of serum cholinesterase at admission and after 24hrs in both survived and died patients. As well, the present study demonstrated that in acute OP poisoning, the serum cholinesterase level at admission or after $24 \mathrm{hrs}$ had no association with the patients' outcomes and cannot predict mortality. This finding is supported by Aygun et al., (2002) who found that low levels of SChE help in the diagnosis of OP poisoning with no correlation with clinical severity. Rehiman et al., (2008) revealed that serum cholinesterase levels at admission did not correlate with mortality, and attributed that to various factors; co-morbidities and inappropriate treatment such as frequent stoppage of atropine infusion. Furthermore, Yardan et al., (2013) clarified absence of significant difference in SChE activity between survivors and non survivors. On the contrary, Chaudhary et al., (2013); Hiremath et al., (2016) observed that low SChE level at admission were associated with bad outcome (prolonged ventilation, ICU and hospital stay) and is a good predictor of organophosphate poisoning mortality. These differences could be attributed to the fact that SChE level exhibit relative variation by several factors; malnutrition, hereditary deficiency, liver diseases, and drugs (as cocaine, codeine, and succinyl choline). So, if the baseline of SChE is not known, it is difficult to relay on it as a biomarker for OP toxicity (Brahmi et al., 2006).

In the present study, significant negative correlation was found between numbers of atropine ampoules and cholinesterase level at admission and after 24hrs. In accordance with that, Avasthi and Singh, (2000); Sungurtekin et al., (2006) revealed that atropine requirement had a negative relation with SChE. Otherwise, Chaudhary et al., (2013); Yardan et al., (2013) showed no correlation between dose of atropine and the serum SChE levels. They asserted that atropine is only a muscarinic receptor antagonist, whereas cholinergic symptoms are associated with overstimulation, to varying degree, of both muscarinic and nicotinic receptors.

As regard, serum S100B level at both admission and after 24hrs, this study revealed significant increase in its level in died patients than survived patients although, it cannot predict mortality. Bozkurt et al., (2010) reported that S100B level was elevated $2 \mathrm{~h}$ after exposure to chlorpyrifos in adult rats revealing usefulness of it in assessment of OP toxicity. Additionally, Yardan et al., (2013) detected that S100B 
level was significantly elevated in nonsurvivors. They found that S100B level over $236.5 \mathrm{pg} / \mathrm{mL}$ was $71.4 \%$ sensitive and $89.7 \%$ specific in predicting mortality and they suggest that S100B may be helpful in predicting the mortality of patients with OP poisoning.

The significant high S100B level after 24hrs of admission in died patients of this study means that there is ongoing brain damage. S-100B has a half life of 2 hours, and its level return to baseline within 12-24 hours. Persistent elevated level after injury reflects continuing secondary brain damage (Raabe et al., 1998).

In the present study, serum S100B level at either admission or after 24hrs revealed significant negative correlation with, numbers of atropine ampoules and SChE level at admission and after 24hrs. Yardan et al., (2013) revealed that S100B correlate negatively with SChE levels and GCS scores but, not with the total dose of atropine administered.

\section{Conclusion}

Both GCS and S100B had significant correlation with the patient's outcome. Inspite of that, only GCS can predict mortality or poor prognosis in $100 \%$ of the patients who has a GCS equal to or lower than 9. Also, $75 \%$ of survivors had GCS above the cut off value.

\section{References}

Abedin MJ, Sayeed AA, Basher A et al., (2012): Open-label randomized clinical trial of atropine bolus injection versus incremental boluses plus infusion for organophosphate poisoning in Bangladesh. J Med Toxicol. 8(2): 108-117.

Akdur O, Durukan P, Ozkan S et al., (2010): Poisoning severity score, glasgow coma scale, corrected QT interval in acute organophosphate poisoning. Hum Exp Toxicol. 29: 419-425.

Ambrozic J, Bunc M, Osredkar J et al., (2008): S100B protein in benzodiazepine overdose. Emerg Med J. 25: 90-92.

Avasthi G and Singh G (2000): Serial neuroelectrophysiological studies in acute organophosphate poisoning - correlation with clinical findings, serum cholinesterase levels and atropine dosages. J Assoc Physicians India. 48:794-799.

Aygun D, Doganay Z, Altintop L et al., (2002): Serum acetylcholinesterase and prognosis of acute organophosphate poisoning. J Toxicol ClinToxicol. 40: 903-910.

Bottiger BW, Mobes S, Glatzer R, et al., (2001): Astroglial protein $\mathrm{S}-100$ is an early and sensitive marker of hypoxic brain damage and outcome after cardiac arrest in humans. Circulation. 103(22): 2694-2698.

Bozkurt A, Yardan T, Ciftcioglu E, et al., (2010): Time course of serum S100B protein and neuronspecific enolase levels of a single dose of chlorpyrifos in rats. Basic Clin Pharmacol Toxicol. 107: 893-898.

Brahmi N, Mokline A, Kouraichi N, et al., (2006): Prognostic value of human erythrocyte acetyl cholinesterase in acute organophosphate poisoning. Am J Emerg Med; 24: 822-827.
Burtis CA and Ashwood ER, (1999): In: Tietz Textbook of Clinical Chemistry, 3d ed. WB Saunders, Philadelphia. Pp. 1917.

Cakir Z, Aslan S, Umudum Z et al., (2010): S-100 beta and neuron-specific enolase levels in carbon monoxide-related brain injury. Am J Emerg Med. 28: 61-67.

Caughlan A, Newhouse K, Namgung U et al., (2004): Chlorpyrifos induces apoptosis in rat cortical neurons that is regulated by a balance between p38 and ERK/JNK MAP kinases. Toxicol Sci. 78: $125-134$.

Chaudhary SC, Singh K, Sawlani KK (2013): Prognostic significance of estimation of pseudocholinesterase activity and role of pralidoxime therapy in organophosphorous poisoning. Toxicol Int. 20(3): 214-217.

Coskun R, Gundogan K, Sezgin GC et al., (2015): A retrospective review of intensive care management of organophosphate insecticide poisoning: Single center experience. Niger J Clin Pract. 18:644-650.

Costa LG (2006): Current issues in organophosphate toxicology. Clin Chim Acta. 366: 1-13.

Davies JO, Eddleston M, Buckley NA (2008): Predicting outcome in acute organophosphorus poisoning with a poison severity score or the Glasgow coma scale. QJM. 101(5):371-379.

Garcia SJ, Seidler FJ, Crumpton TL et al. (2001): Does the developmental neurotoxicity of chlorpyrifos involve glial targets? Macromolecule synthesis, adenylyl cyclase signaling, nuclear transcription factors and formation of reactive oxygen in C6 glioma cells. Brain Res. 891: 54-68.

Guizzetti M, Pathak S, Giordano G et al., (2005): Effect of organophosphorus insecticides and their metabolites on astroglial cell proliferation. Toxicol. 215:182-190.

Hiremath P, Rangappa P, Jacob I et al., (2016): Pseudocholinesterase as a predictor of mortality and morbidity in organophosphorus poisoning. Indian J Crit Care Med. 20: 601604.

Hosseini M and Ramazani J (2015): Comparison of acute physiology and chronic health evaluation II and Glasgow Coma Score in predicting the outcomes of post anesthesia care unit's patients. Saudi J Anaesth. 9(2): $136-141$.

Jokanović M (2009): Medical treatment of acute poisoning with organophosphorus and carbamate pesticides. Toxicol Lett. 190: 107115.

Karanth S, Liu J, Mirajkar N et al., (2006): Effects of acute chlorpyrifos exposure on in vivo acetylcholine accumulation in rat striatum. Toxicol Appl Pharmacol. 216:150-156.

Kumar SV, Fareedullah Md., Sudhakar Y et al., 2010): Current review on organophosphorus poisoning. Arch Appl Sci Res. 2 (4):199- 215. 
Lee JH, Lee YH, Park YH et al., (2013): The difference in C-reactive protein value between initial and 24 hours follow-up (D-CRP) data as a predictor of mortality in organophosphate poisoned patients. Clin Toxicol. (Phila) 51(1):29-34.

Muley A, Shah C, Lakhani J et al., (2014): To identify morbidity and mortality predictors in acute organophosphate poisoning. Indian J Crit Care Med. 18(5): 297-300.

Qiao D, Seidler FJ, Slotkin TA (2001): Developmental neurotoxicity of chlorpyrifos modeled in vitro: comparative effects of metabolites and other cholinesterase inhibitors on DNA synthesis in PC12 and C6 cells. Environ Health Perspect. 109:909-913.

Raabe A, Menon D K, Gupta S et al., (1998): Jugular venous and arterial concentrations of serum S100B protein in patients with severe head injury: a pilot study. J Neurol. Neurosurg. Psychiatry. 65: 930-932.

Rehiman S, Lohani SP, Bhattarai MC (2008): Correlation of serum cholinesterase level, clinical score at presentation and severity of organophosphorous poisoning. JNMA J Nepal Med Assoc. 47: 47-52.

Rothermundt M, Peters M, Prehn JH et al., (2003):S100B in brain damage and neurodegeneration. Microsc Res Tech. 60:614-632.

Sam KG, Kondabolu K, Pati D et al., (2009): Poisoning severity score, APACHE II and GCS: effective clinical indices for estimating severity and predicting outcome of acute organophosphorus and carbamate poisoning. J Forensic Leg Med. 16: 239-247.

Shahin M M, Abuelfadle A A, Zaki ANM (2016): The potential role of S-100B protein in evaluation of CNS affection of mortality in acute phosphide intoxication. Ain Shams Journal of Forensic Medicine and Clinical Toxicology. 26: 7-15.

Sun O, Yoon HJ, Lee KY (2015): Prognostic factors in cholinesterase inhibitor poisoning. Med Sci Monit. 21: 2900-2904.

Sungurtekin H, Gürses E, Balci C (2006): Evaluation of several clinical scoring tools in organophosphate poisoned patients. Clin Toxicol (Phila). 44: 121-126.

Tien HC, Cunha JR, Wu SN et al., (2006): Do trauma patients with a Glasgow Coma Scale score of 3 and bilateral fixed and dilated pupils have any chance of survival? J Trauma. 60(2):274278.

Unde'n J and Romner B (2009): A new objective method for CT triage after minor head injury serum S100B. Scand J Clin Lab Invest. 69 (1): 13-17.

Yardan T, Cevik Y, Donderici O et al., (2009): Elevated serum S100B protein and neuronspecific enolase levels in carbon monoxide poisoning. Am J Emerg Med. 27: 838-842.

Yardan T, Baydin A, Acar E et al., (2013): The role of serum cholinesterase activity and S100B protein in the evaluation of organophosphate poisoning. Hum Exp Toxicol. 32(10): 10811088.

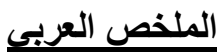

\section{التنبؤ بحالات التسمم الحاد بالفوسفات العضوي باستخدام مقياس جلاسكو كوما و الكولين استيريز (S100B) و البروتين (SCHE)}

\author{
مرفت عريبي وايناس ابراهيم المداح| \\ خلفية عن البحث: ان النسمم بمركبات الفوسفات العضوي (OP) مشكلة صحية كبيرة في جميع أنحاء العالم، وخاصة في البلدان النامية، مع

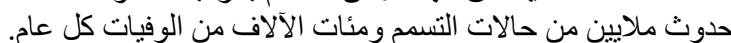

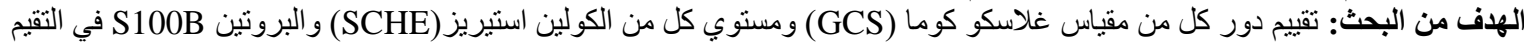

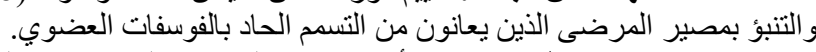

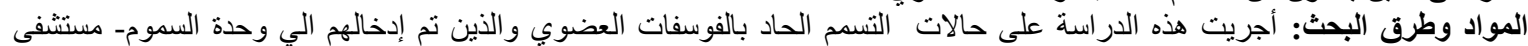

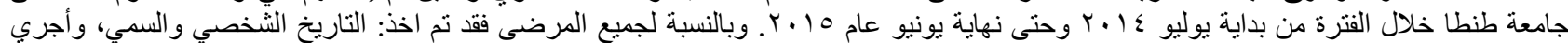

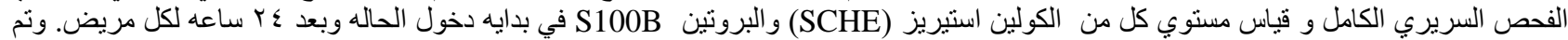

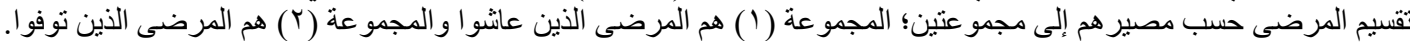

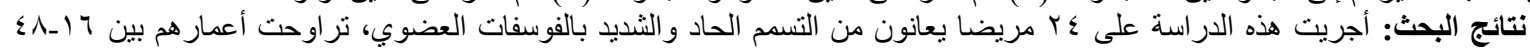

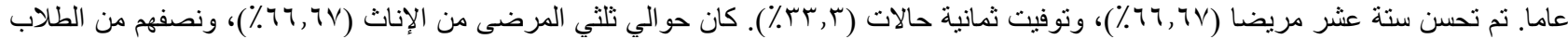

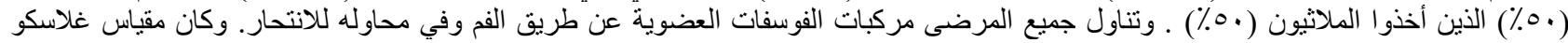

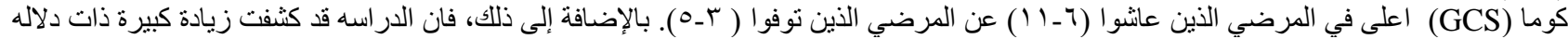

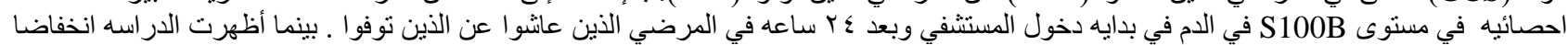

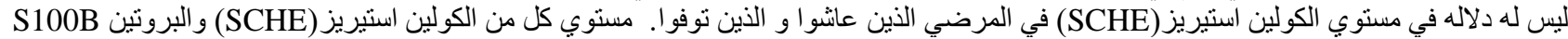

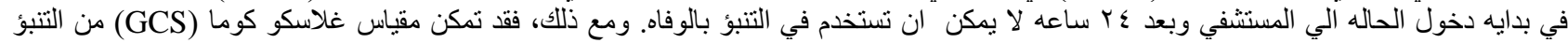

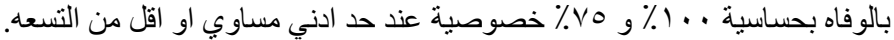

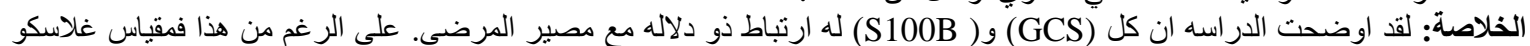

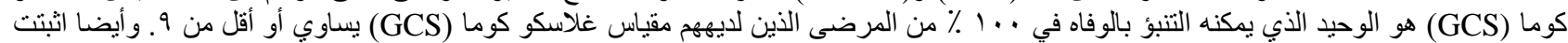

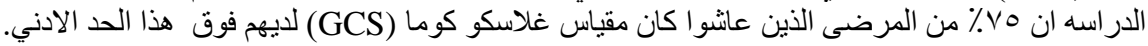

